\title{
POWSTANIE I DZIAŁALNOŚĆ TRZECIEGO ZAKONU ŚW. FRANCISZKA Z ASYŻU W SOKOLOWIE MALOPOLSKIM DO ROKU 1939
}

Schyłek XIX oraz pierwsze dziesięciolecia XX wieku w całym Kościele polskim zaowocowały powstaniem i rozwojem licznych zrzeszeń o charakterze religijnym. Wśród nich nie brakło cechów rzemieślniczych i usługowych, bractw kościelnych oraz innych organizacji i stowarzyszeń religijnych. Nie inaczej było w parafii pw. św. Jana Chrzciciela w Sokołowie Małopolskim w diecezji przemyskiej, położonej wpierw w dekanacie leżajskim, zaś od roku 1921 - w nowo powołanym dekanacie sokołowskim. Szczególnym przejawem aktywności laikatu na terenie tejże parafii była także Świecka Rodzina Zakonna, która odegrała dużą role w ówczesnym duszpasterstwie wiernych. Była ona jedynym w swoim rodzaju zespołem religijnym istniejącym w tej wspólnocie parafialnej, a owa wyjątkowość wynikała z faktu, że organizacja tercjarska pozostawała prawdziwym zakonem.

Kanoniczne erygowanie Trzeciego Zakonu Franciszkańskiego w parafii sokołowskiej poprzedzone było wieloma próbami założenia tercjarstwa. Usiłowania te trwały przez kilkadziesiąt lat, co świadczy o dużej determinacji wiernych w tej kwestii. Wydarzenia te rzutowały później na całą działalność Trzeciego Zakonu w Sokołowie. Warto zatem nie tylko przedstawić tę działalność, lecz także okoliczności, w jakich tercjarstwo pojawiło się w sokołowskiej wspólnocie parafialnej.

\section{Geneza sokolowskiego tercjarstwa}

Poczatki franciszkańskiego tercjarstwa w Sokołowie sięgają końca XIX stulecia. Trudno co prawda ustalić dokładny czas zaistnienia Trzeciego Zakonu w tej parafii, niemniej jako date orientacyjną można przyjąć rok 1890 . Wtedy to jedna z mieszczanek sokołowskich, Katarzyna Koziarz ${ }^{1}$ została przyjęta do Świeckiej

* Bartosz Walicki - dr historii, dyrektor Miejskiej i Gminnej Bibl. Publ. w Sokołowie Małop.

${ }^{1}$ Była to siostra głośnego w Kościele polskim teologa ks. Szczepana Szydelskiego (Koziarza). 
Rodziny Franciszkańskiej w Rzeszowie. Od tej pory zaczęła szerzyć w rodzinnej parafii ideę tercjarstwa, znajdując wielu naśladowców $w^{2}$.

Rozwój Trzeciego Zakonu był dosyć szybki ${ }^{3}$. Od początku zarysowała się różnica-w szeregi tercjarzy wstępowało o wiele więcej osób mieszkających w okolicznych wioskach niż w samym mieście. Być może przyczyną tego był fakt, że mieszczanie skupiali się raczej w lokalnych bractwach i stowarzyszeniach kościelnych, których członkowie rzadziej pochodzili ze wsi. A może wynikało to stąd, że w wioskach żyli ludzie mocniej przywiązani do Kościoła i posiadający pobożność bardziej skłonną do podejmowania różnych dzieł ascetycznych.

O ile w Sokołowie działała wspomniana już Katarzyna Koziarz, to w wioskach, należących do parafii, propagowaniem tercjarstwa zajmowały się inne osoby. „Na Wólce Sokołowskiej zajmowała się III Zakonem i zapisywała do niego Marya Ożóg, a później Małgorzata Maksym jako przełożona. W Trzebusce była przełożona Katarzyna Bąk"4. Podkreślić należy, iż w początkowym okresie - a zapewne również później - tercjarstwo zdominowały kobiety, mężczyźni zaś byli w nim raczej nieliczni.

Chociaż wielu z parafian sokołowskich należało do Trzeciego Zakonu, długo jednak w Sokołowie nie tworzono osobnej gminy tercjarskiej. Gmina taka było to ,zjednoczenie tercjarzy i tercjarek tej samej miejscowości lub parafii w związku legalnym, to jest: założonym kanonicznie, urządzonym według przepisów reguły, z oznaczeniem stałej przynależności do któregoś kościoła lub kaplicy"s. Przez około trzydzieści lat sokołowianie przyjmowani byli do grona tercjarzy tam, gdzie istniała już Świecka Rodzina Franciszkańska - w Leżajsku i Rzeszowie ${ }^{6}$. Było to możliwe, gdyż w miejscowościach tych tercjarze istnieli przy kościołach prowadzonych przez franciszkanów?

„III Zakon w Sokołowie powstał około r. 1890. Mianowicie przyjechała do Sokołowa jedna z sióstr i pouczyła Katarzynę Koziarz o III Zakonie, tak iż ta wstapiła do III Zakonu w Rzeszowie, a za nią jej koleżanki". Zbiory autora [dalej: AAW], [b.s.], Kronika Trzeciego Zakonu Św. O. Franciszka w Sokołowie Małopolskim

Inne informacje przekazuje kronika tercjarska. „Trzeci Zakon w Sokołowie rozwijał się jednak bardzo powoli" (tamże). Na zwarte tam opinie trzeba jednak spojrzeć krytycznie. Tercjarze nie byli zwykłym bractwem, gdyż stanowili uznaną przez prawo kanoniczne i dokumenty kościelne rodzinę zakonną. Trudno było spodziewać się, by organizacja ta była masową. Autor kroniki, piszący z perspektywy wielu lat, patrzył przez pryzmat ówczesnej sytuacji, gdy kongregacja sokołowska liczyła kilkudziesieciu członków. W porównaniu z tym pierwsze lata Trzeciego Zakonu w parafii jawić się mogły jako bierne i nie odnotowujące znaczniejszych sukcesów. Rzeczywistość była chyba nieco inna. Tercjarstwo musiało torować sobie drogę pośród innych organizacji religijnych i z trudem zdobywać nowych członków, którzy spełnialiby wymagane warunki i decydowali się na podjęcie nielekkich przecież obowiazków. W świetle tego widać, że Trzeci Zakon był dość aktywny i rozwijał się nader szybko.

${ }^{4}$ Tamże. Na innym miejscu źródło to podaje, iż Katarzyna Bąk była przełożoną w Trzebosi. Jest to na pewno błąd, jako że Trzeboś tworzyła osobną parafię.

${ }^{5}$ Cz. Bogdalski, Organizacja i działalność III Zakonu Ś. O. Franciszka, Kraków 1926, s. 26.

6 "Siostry zapisywały się najczęściej w Rzeszowie lub w Leżajsku”. Kronika Trzeciego Zakonu.

${ }^{7}$ Bogdalski, Organizacja i dzialalność III Zakonu, s. 26.
Sokołowscy tercjarze mieszkali w swojej parafii i w niej rozwijali działalność, lecz mimo to nie organizowali swoich zebrań w mieście. Na spotkania formacyjne i modlitwy wspólnotowe jeździli do Rzeszowa lub Leżajska. Ówczesny proboszcz sokołowski ks. Franciszek Stankiewicz nie był najwyraźniej zwolennikiem Trzeciego Zakonu, gdyż mimo próśb parafian nie poczynił żadnych starań, by erygować gminę tercjarską w Sokołowie. Nie zezwolił również na urządzanie zebrań tercjarskich na terenie parafii ${ }^{8}$

Brak gminy tercjarskiej w Sokołowie czy choćby tylko odbywania się spotkań tutejszych członków Trzeciego Zakonu na pewno był przyczyną hamującą w jakimś stopniu jego rozwój. $Z$ tego też powodu, poprzez pozorną bierność, brak zakorzenienia w rodzimych formach pobożności oraz poprzez małe zainteresowanie ze strony księży, Trzeci Zakon postrzegany był przez ogół sokołowian jako mało atrakcyjny. Równocześnie osłabiał się zapał i gorliwość tercjarzy, żyjących niejako w rozproszeniu.

W omawianej parafii istniała więc wówczas pilna potrzeba utworzenia gminy tercjarskiej, a przynajmniej organizowania regularnych zebrań sokołowskich członków tej wspólnoty i troski o nich ze strony miejscowych duszpasterzy. To, że członków tej wspólnoty i troski o nich ze strony miejscowych duszpasterzy. To, ze kongregacji Trzeciego Zakonu, było na pewno dużym zaniedbaniem ze strony duszpasterzy. Do założenia Świeckiej Rodziny Zakonnej wystarczały bowiem zaluszpasterzy. Do założenia Swieckiej Rodziny Zabo i to nawet bez profesji zakonnej.

Starania, by ks. Franciszek Stankiewicz zajął się kanoniczną erekcją gminy tercjarskiej, nie przyniosły wiekszych skutków. Co prawda proboszcz zainteresował się bliżej tą sprawą, niemniej nie poczynił w tym względzie żadnych poważniejszych zabiegów. Wiekssze nadzieje tercjarze wiązali z osobą następnego proboszcza ks. Leona Szado. On jednak również nie zadbał o prawne zaprowadzenie Trzeciego Zakonu w Sokołowie. Zauważyć natomiast trzeba, iż dostrzegając istniejące potrzeby, organizował co jakiś czas spotkania członków Świeckiej Rodziny Franciszkańskiej i próbował angażować ich do pracy w kościele.

Ważnym i bogatym w skutki faktem było to, że ks. Leon Szado uzyskał od oo Kapucynów władzę przyjmowania nowych członków do Trzeciego Zakonu9 Udzielenie miejscowemu proboszczowi tej władzy ${ }^{10}$ było dużym krokiem na drodze ku kanonicznemu utworzeniu wspólnoty tercjarzy w parafii. Poprzez to sokołowianie nie musieli już wędrować do Leżajska lub Rzeszowa, gdzie znajdowal się zakonnicy franciszkańscy mogący przyjąć ich do grona Trzeciego Zakonu.

8 Zebrań tercjarzy za św. pamięci Ks. Stankiewicza nie było wcale, gdyż [siostry] uczęszczały "Zebran tercjarzy za sw. pamiç siostry postanowiły prosić byłego wówczas Przew[ielebnego] Ks. Dziekana Stankiewicza, by te zebrania odbywały się w Sokołowie". Kronika Trzeciego Zakonu.

$\vartheta$ „....) Ojcowie kapucyni, którzy czasami za okazyi czterdziestogodzinnego nabożeństwa przyjeżdżali do Sokołowa, udzielili Przew[ielebnemu] Ks. Szadzie władzy przyjęcia do III Zakonu”. Kronika Trzeciego Zakonu.

${ }_{10}$ Por. Ustawy $i$ zwyczaje Trzeciego Zakonu Ś. O. Franciszka dla Tercyarzy Stowarzyszonych świeckich, czyli wykład Trzeciej Reguly św. Franciszka zreformowanej przez Leona XIII z zastosowaniem do Zgromadzeń Tercyarskich, Kraków 1896, s. 40-41. 
Szybciej zwiększała się liczba tercjarzy w parafii, a równolegle do tego rosło ich znaczenie ${ }^{11}$.

Członkowie Franciszkańskiego Zakonu Świeckich stawiali przed sobą cele, do osiagnięcia których dążyli. Było to m.in. zbliżanie się do ideału doskonałego chrześcijanina, a także podejmowanie pracy, by duchem wiary katolickiej przeniknąc instytucje rodziny i społeczeństwa. Drogą w realizacji tych zadań miały być dla tercjarzy wymagania, jakie nakładała na nich reguła. Na zobowiązania te składały się: przestrzeganie przykazań Bożych i kościelnych, wierność nauczaniu papieża i biskupów, modlitwa i czeste uczestniczenie we Mszy św., comiesięczna spowiedź św. i praktykowanie codziennego rachunku sumienia, popieranie dzieł miłosierdzia, dawanie dobrego przykładu w życiu rodzinnym i społecznym, zachowywanie nakazanych postów, umiarkowanie w jedzeniu i piciu, skromność w strojach i rozmowach, unikanie tańców, nieprzyzwoitych przedstawień i wszelakich zbytków.

Jeszcze przed erygowaniem Trzeciego Zakonu w parafii sokołowskiej tercjarze prowadzili w niej dosyć szeroką działalność. Otoczyli szczególną opieką budowany kościół parafialny i wyposażenie świątyni. Informuje o tym dokładniej kronika tercjarska. Przekazuje ona, że przykładem troski tercjarzy było wyzłocenie jednej puszki, a także sprawienie ornatu, czterech obrusów na ołtarz i jednego pluszowego nakrycia ${ }^{12}$. Aby zwiększyć kult swojego patrona staraniem członków Zakonu nabyto również obraz św. Franciszka do ołtarza bocznego ${ }^{13}$.

Nie uchylali siẹ również tercjarze od składania ofiar pieniężnych na cele kościelne. Do tego byli niejako zobowiązani już przez samą swoją przynależność do Zakonu ${ }^{14}$. Proszeni przez proboszcza o wsparcie finansowe, trzykrotnie złożyli na cele kościelne ofiary w wysokości kilkudziesieciu zł. Kwoty te przeznaczone zostały m.in. na kupno cyborium oraz na wynagrodzenie stolarzy wykonujących balaski i ławki do kościoła farnego. Prócz tego tercjarze zajęli się kwestą na figu-

"Tercjarze zaczęli powoli wchodzić w sferę zainteresowań duszpasterzy. Ciekawe jest, że do roku 1934 w sprawozdaniach $\mathrm{z}$ wizytacji dziekańskich nie ma w ogóle mowy o Trzecim Zakonie w Sokołowie. Wspólnota ta, dosyć przecież liczna, wspominana jest tylko raz: „Tercjarstwo Zakon liczy kilkadziesiąt członków". Poza tym pierwszy raz tercjarze wymienieni zostali dopiero po opuszczeniu stanowiska proboszcza przez ks. Leona Szado. Por. Archiwum Archidiecezjalne w Przemyślu [dalej: AAP], L. Szado, Sprawozdanie ze stanu religijnego parafii Sokołów z 25 sierpnia 1927 r. [rkps]; AAP, L. Kordyl, Sprawozdanie o stanie parafii za czas 4/X 1934-4/XI 1934 nia 1927

${ }^{12}$ „Za św. pamięci Ks. Stankiewicza Trzeci Zakon w Sokołowie rozwijał po największej części pracę kościelną. Postarał się o wyzłocenie puszki i sprawienie ornatu, do którego dołożył Ks. Dziekan Stankiewicz. Zakupiono przy tem 4 obrusy na ołtarz i jedno nakrycie pluszowe". Kronika Trzeciego Zakonu.

${ }^{13}$ „,(...) siostry uchwaliły, że przy ukończeniu nowego kościoła będą się starały zakupić ze składek obraz św. Franciszka i wstawić go do ołtarza. Ksiądz Stankiewicz zaproponował, żeby zbierać składki i złożyć je w Kasie Stefczyka, tymczasem on postara się o zakup pięknego obrazu. Było już złożone na ten cel 360 koron. Niestety, Ks. Dziekan Stankiewicz wkrótce zmarł. (...) Za Przew. Ks. Szady kupiono przepiękny obraz św. Franciszka i umieszczono go w oltarzu. Obraz ten kosztował 400 koron". Tamże.

${ }^{14}$ Por. Ustawy i zwyczaje, s. 122-123. rę św. Antoniego i prowizoryczny ołtarz, białe chorąwie oraz ozdobne świece ${ }^{15}$. Sokołowska wspólnota Świeckiej Rodziny Franciszkańskiej przyjęła na siebie także cześciowa troskę o wystrój świątyni farnej, przystrajanie ołtarzy i czyszczenie bielizny kościelnej. Co pewien czas tercjarze byli fundatorami stypendiów mszalnych. W intencjach swych pamiętali o papieżu, o żywych i zmarłych dobroczyńcach oraz o potrzebujących modlitwy ${ }^{16}$.

Do roku 1934 wspólne spotkania sokołowskich tercjarzy były rzadkie albo nie organizowano ich wcale. W początkowym okresie tutejsi członkowie Zakonu dojeżdżali na spotkania do kościołów prowadzonych przez oo. Bernardynów. Nie było to jednak takie łatwe, ponieważ odległość ta wynosiła ok. $25 \mathrm{~km}$, co na ówczesne warunki było dość daleko. Specjalne spotkania tercjarskie w Sokołowie zaprowadził proboszcz ks. Leon Szado. Zgromadzenia te odbywały się dość rzadko, bo dwa-trzy razy do roku ${ }^{17}$. Było to o wiele dogodniejsze dla tercjarzy z parafii, ale w dalszym ciągu nie zaspokajało dostatecznie ich potrzeb dewocyjnych.

Jakkolwiek znane zachowane dokumenty archiwalne nie wspominaja, aby rzadca parafii skarżył się na obecność i działalność tercjarzy w Sokołowie, to przypuszczać można, że z pewnością traktował ich nieco z rezerwą. Choć bowiem chêtnie korzystał z ich pomocy, zwłaszcza finansowej, nie uczynił właściwie nic w celu zaprowadzenia kongregacji zakonnej w parafii sokołowskiej. Być może duch Świeckiej Rodziny Franciszkańskiej był mu obcy. Możliwe również, że obawiał się on zbytniego wpływu tercjarstwa na parafian. Gdyby tak było, postawa ks. Leona Szado nie stanowiłaby żadnego ewenementu ${ }^{18}$.

\section{Kanoniczne zalożenie kongregacji sokolowskiej}

Poważniejsze działania mające na celu kanoniczne erygowanie Trzeciego Zakonu w Sokołowie Małopolskim poczynił dopiero ks. Ludwik Bukała. Po przyjściu do parafii szybko zauważył w niej istnienie ,niezrzeszonych” tercjarzy. Sokołowska kronika tercjarska informuje, że nowy proboszcz, objąwszy parafię po swoim poprzedniku, również urządzał zebrania dla członków Trzeciego Zakonu. Wygłaszał na nich m.in. nauki poświęcone tercjarstwu. Spotkania te odbywały się przynajmniej w każdą trzecią niedzielę miesiąca.

${ }_{15}$ „Przy ukończeniu nowego kościoła Przew[ielebny] Ks. Leon Szado po trzy razy zwracał się do Tercyarzy z prośbą o pomoc i zawsze otrzymywal po kilkadziesiąt zł, którą to sumę obracano bądź na cymboryum, balaski lub ławki. (...) Zajmował się [Trzeci Zakon] składką na statuę św. Antoniego i prowizoryczny ołtarz, ozdobne świece i białe choragwie". Kronika Trzeciego Zakonu.

16 .Sprawił też III Zakon pelerynki dla ministrantów, alby i komże. (...) Zajmował się praniem bielizny kościelnej i przystrajaniem ołtarzy. W tym także czasie siostra Zofia Sikora z Turzy zbierała datki, z których kupiono bieliznę do kościoła, nakrycie na ambonę i ołtarz. Piękosiowa Aniela zrobiła nakrycia na ambonę i poduszki. Eleonora Piękoś zrobiła kilka razy kwiaty na ołtarze. (...) Msze św. zamawiano jeden lub 2 razy miesięcznie w intencji Ojca św., za żywych lub umarłych”. Tamże.

18 Por Sprawozdanie z kongregacji dekanalnej odbytej w r. 1900, 1901, 1902 (dokończenie), „Kronika Dyecezyi Przemyskiej”, 5 (1903) s. 211. 
Rządca parafii wielokrotnie obiecał także, że w bliskiej przyszłości zajmie się uregulowaniem sprawy tercjarstwa w Sokołowie. W postawie proboszcza dostrzegane było zaangażowanie w tej kwestii, wierni cenili troske i zainteresowanie widoczne $\mathrm{z}$ jego strony ${ }^{19}$. Przychylna postawa ks. Ludwika Bukały zaowocowała kanonicznym zaprowadzeniem kongregacji tercjarskiej, co miało to miejsce w maju 1936 roku $^{20}$. Było to 16 miesięcy po zainstalowaniu ks. Ludwika Bukały na probostwie sokołowskim ${ }^{21}$. Pertraktacje proboszcza z Bernardynami trwały już od pewnego czasu. W dniu 27 kwietnia 1936 r. przybył do Sokołowa wizytator zakonny z Rzeszowa - o. Wiktor Biegus ${ }^{22}$. Zakonnik zaznajomił się na miejscu ze stanem tercjarstwa w parafii. Odbył też konferencję z członkami Świeckiej Rodziny Franciszkańskiej. Po zasięgnięciu opinii proboszcza ustalił on datę erygowania Trzeciego Zakonu na dzień 24 maja.

W międzyczasie ks. Ludwik Bukała postarał się o zezwolenie na kanoniczna erekcje kongregacji tercjarskiej w Sokołowie u ordynariusza przemyskiego bpa Franciszka Bardy ${ }^{23}$. Biskup przemyski chętnie wyraził na to zgodę. Odpowiednie zezwolenie przysłał proboszczowi sokołowskiemu już 4 maja $1936 \mathrm{r}^{24} \mathrm{~W}$ wigilię erygowania Trzeciego Zakonu ponownie przybył do parafii o. Wiktor Biegus. Odbyła się wówczas jego narada z przełożoną tercjarzy Katarzyną Koziarz. Do wydarzenia, jakie nastapiło nazajutrz, wszyscy tercjarze przygotowywali się poprzez przystapienie do sakramentu spowiedzi św. Oprócz tego osobiście spotkali się z wizytatorem na plebanii.

Oficjalne zaprowadzenie kongregacji zakonnej w Sokołowie odbyło się podczas sumy w niedziele 24 maja $1936 \mathrm{r}^{25} \mathrm{Na}$ uroczystość tę przybyli tercjarze z pobliskich parafii: Górna, Medyni, Nienadówki, Rakszawy i Trzebosi. Wizytator

${ }^{19}$ Tercjarze nie wahali się zapisać w swojej kronice: „Dopiero prawdziwym zrozumieniem dla spraw III Zakonu i jego potrzeb odznacza sie nastepca ks. Szady, Przewielebny Ks. Dziekan Bukała (...). Jemu to jedynie zawdzięcza Tercyarstwo, że obecnie zebrania odbywają się stale co drugą niedzielę miesiąca (...)". Por. Kronika Trzeciego Zakonu.

${ }^{20} \mathrm{~W}$ tym samym czasie powstała kongregacja Zakonu w sąsiedniej parafii Górno. Pierwsza tercjarka z tej wsi złożyła profesję w roku 1895. Kanoniczne erygowanie Trzeciego Zakonu miało tam miejsce 19 stycznia $1936 \mathrm{r}$. Ta wspólnota - inaczej niż sokołowska - powiazana była jednak z klasztorem leżajskim. Por. K. Ożóg, Dzieje parafii Górno 1599-1999, Górno-Rzeszów 1999, s. 139.

${ }^{21}$ Ks. Ludwik Bukała przeszedł na probostwo w Sokołowie 14 stycznia 1935 r. Por. AAP, Tabela służbowa ks. Ludwika Bukały.

${ }^{22} \mathrm{O}$. Wiktor Biegus przez pewien czas pozostawał na stanowisku dyrektora rzeszowskiej gminy tercjarskiej. W pełnieniu tej funkcji w szczególny sposób odznaczył się solidną pracą i osobistym zaangażowaniem. Por. A. Motyka, Życie religijne w Rzeszowie w okresie międzywojennym (1918-1939), Lublin-Rzeszów 2000, s. 183.

${ }^{23}$ „Upraszam Waszą Ekscelencję o laskawe zezwolenie na kanoniczną erekcję Kongregacji III Zakonu ś. Franciszka przy tutejszym kościele parafialnym. Tercjarzów jest w tutejszej parafii około 100. Jedni zostali przyjęci w Klasztorze OO. Bernardynów w Leżajsku, inni w Rzeszowie, innych przyjmowali OO. Kapucyni, którzy tu nieraz głoszą kazania na 40godz. Nabożeństwie. Wypada ich tedy zjednoczyć". AAP, L. Bukała, List do biskupa przemyskiego z 2 maja 1936 r

${ }^{24} \mathrm{AAW}$, Diploma erectionis et directionis Tertii Ordinis Sancti Patris Francisci.

${ }^{25}$ Tercjarze przystapili do Komunii św. na prymarii celebrowanej przez o. Wiktora Biegusa. Suma została odprawiona przez ks. Ludwika Bukałę; wizytator wygłosił po niej kazanie o św. Franciszku i o założeniu przez niego trzech zakonów. zamianował też zarząd kongregacji, co było zgodne z przepisami ${ }^{26}$. Podczas urozzystego erygowania zakonu, sokołowscy tercjarze jako swojego patrona obrali św. Ludwika ${ }^{27}$ Z tej okazji odczytano również listę nowicjuszy tercjarskich ${ }^{28} . \mathrm{Ob}-$ łóczonych zostało też dziesięć osób z sąsiedniej parafii nienadowskiej. Kontynuacja uroczystości były nieszpory. Po nich nastapiło walne zebranie tercjarzy. Rozegrało sie ono na miejscowej plebanii ${ }^{29}$. Skład zarządu kongregacji sokołowskiej I kadencji przedstawia poniższa tabela.

\begin{tabular}{|c|c|c|c|}
\hline \multicolumn{3}{|c|}{ Funkcja w zarządzie ${ }^{1}$} & Imię i nazwisko osoby ją piastującej \\
\hline \multicolumn{3}{|c|}{ Dyrektor } & Ks. Ludwik Bukała \\
\hline \multirow{10}{*}{ 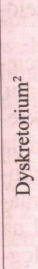 } & \multicolumn{2}{|c|}{ Siostra przełożona } & Katarzyna Koziarz \\
\hline & \multicolumn{2}{|c|}{ Siostra asystentka } & Maria Krauz z Trzebuski \\
\hline & \multicolumn{2}{|c|}{ Siostra mistrzyni nowicjatu } & Eleonora Piękoś z Sokołowa \\
\hline & \multicolumn{2}{|c|}{ Siostra sekretarka } & Aniela Piękoś z Sokołowa \\
\hline & \multicolumn{2}{|c|}{ Siostra infirmerka } & Franciszka Węglowska z Sokołowa \\
\hline & \multirow{5}{*}{ 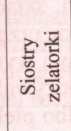 } & dla Rękawa & Aniela Bąk \\
\hline & & dla Sokołowa & Maria Koziarz \\
\hline & & dla Trzebuski & Anna Ciupak, Anna Surowiec \\
\hline & & dla Turzy & Zofia Sikora \\
\hline & & dla Wólki Sokołowskiej & Julia Maksyn, Katarzyna Rychel, Agnieszka Szób \\
\hline
\end{tabular}

' Zarząd kongregacji sokołowskiej różnił się od ,zarządu wzorcowego". Nie istniały w nim - przynajmniej na początku - stanowiska: bibliotekarki, chórzystek, furtianki, jałmużniczki, mistrzyni ceremonii, skarbniczki, zakrystianki i siostry zarządzającej westyarniq (pomieszczeniem, w którym przechowywane były ubrania, przywdziewane przez braci i siostry na zebrania tercjarskie i wspólnotowe obrzeddy). Nie powinno to jednak wcale dziwić, gdyż urzędy te nie były konieczne. Liczbę i rodzaj istniejących urzędów dostosowywano do panujących warunków i potrzeb. Zresztą w późniejszym okresie przynajmniej niektóre z tych funkcji utworzono w kongregacji sokołowskiej. ${ }^{2}$ Dyskretorium, zwane także Zwierzchnością Tercjarska, to grupa tych członków kongregacji, którym poruczone zostały urzędy w zarządzie i tych, których wybrano jako doradców, choć nie posiadal żadnej funkcji.

Dyrektorem ${ }^{30}$ sokołowskiej kongregacji został miejscowy proboszcz. Było to optymalne rozwiązanie. Dzięki temu działalność tercjarzy nie pozostawała w opozycji do decyzji rządcy parafii, a całe duszpasterstwo mogło przebiegać sprawniej

${ }^{26}$ Por. Regula Trzeciego Zakonu Świętego Ojca Franciszka Serafickiego dla osób w świecie żyjacych, w: Przewodnik Modzieży Franciszkańskiej, opr. G. Moczygęba, Katowice 1938, s. 47.

${ }^{27}$ Św. Ludwik - na równi ze św. Elżbietą Wegierską - był głównym patronem Franciszkańskiego Zakonu Świeckich.

${ }^{28}$ Imiona i nazwiska nowicjuszy podaje kronika tercjarska. Byli to - z Wólki Sokołowskiej: arali Barciniec, Agnieszka Matuła, AgRozalia Bęen, (1) Katrorolina Zagaja; z Kątów Trzebuskich: Katarzyna Kołodziej; z Sokołowa: Maria

ria Bakk, Andrzej Lachtara, Franciszka Piękoś. Por. Kronika Trzeciego Zakonu.

${ }^{29} \mathrm{O}$ spotkaniu tym informuje kronika tercjarska. „,...) tu odczytano listę członków, a O. Wizytator udzielił wszystkim odpowiedniednie wskazówki od O. Wizytatora" banji, na

${ }^{30}$ Ustawy i zwyczaje, s. 138; Bogdalski, Organizacja i dzialalność III Zakonu, s. 41 
i być znacznie owocniejsze. Stanowiło to zarazem odpowiedź na apel przemyskiej Kurii Biskupiej, która wzywała kapłanów do zainteresowania sie sprawa tercjarzy i zachęcała wiernych do wstępowania do Trzeciego Zakonu Franciszkańskiego ${ }^{31}$.

Rzeczywistą kierowniczką grona tercjarzy była siostra przełożona. Ona właściwie zarzadzała nim, jako że dyrektor roztaczał nad Trzecim Zakonem jedynie duchową opiekę oraz czuwał, by kierownictwo przełożonej nie wykraczało poza Regułę i by nie przyniosło szkody kongregacji. Siostra przełożona, nawet po ukończeniu kadencji sprawowanej władzy, do końca życia zachowywała prawo przynależenia do dyskretorium. Siostra asystentka posiadała teoretycznie te same uprawnienia co przełożona. Była jej zastępczynią i pomocnicą. Ze swojej władzy mogła korzystać jedynie w przypadku nieobecności, choroby albo śmierci przełożonej.

Mistrzyni nowicjatu przyjmowała obowiązki badania postulantek do Trzeciego Zakonu, pouczania ich o istocie tercjarstwa oraz opieki podczas nowicjatu. Dość liczne funkcje- notariusza i pisarza zgromadzenia - spełniała siostra sekretarka. Prowadziła ona księgi kongregacji, spisywała protokoły zebrań, składała sprawozdania z działalności Trzeciego Zakonu oraz sporządzała wszelkie urzędowe akta, ogłoszenia i prowadziła korespondencje.Trudny, pracochłonny i wymagający poświęcenia obowiązek odwiedzania i pomagania chorym spoczywał na siostrze infirmerce. Nazywana była ona również opiekunką chorych albo pielęgniarka. Często stanowisko to obejmowały osoby znające nieco arkana medycyny. Infirmerka miała także za zadanie przygotować pacjentów do przyjęcia sakramentu namaszczenia chorych, a w przypadku śmierci chorego - jeśli byłaby taka potrzeba - zajać się również pogrzebem. Siostry zelatorki mianowano wówczas, gdy Trzeci Zakon istniał w dużym mieście lub w parafii składajacej sie z kilku miejscowości. Zelatorka była zwierzchniczką tercjarzy w pewnej dzielnicy albo wiosce (lub jej części). Miała ona czuwać nad powierzonymi sobie siostrami, upominać je w razie konieczności oraz pomagać w potrzebach, a nade wszystko informować o zaleceniach dyrektora i siostry przełożonej.

\section{Rozwój i działalność Trzeciego Zakonu}

Po kanonicznym erygowaniu kongregacji tercjarze rozwinęli prężną działalność, która jeszcze przed rokiem 1936 - jak wcześniej wspomniano - była dosyć szeroka. Członkowie Świeckiej Rodziny Franciszkańskiej byli fundatorami róż nych szat liturgicznych i sprzętów kościelnych. Większość środków finansowych uzyskiwali drogą dobrowolnych składek ${ }^{32}$, do czego nakłaniała w pewnym sensie

${ }^{31}$ Odezwa Generalnego Sekretarza III Zakonu w sprawie III Zakonu św. Franciszka z Assyżu, „Kronika Diecezji Przemyskiej”, 1927, z. 3, s. 92-93.

${ }^{32}$ „W tym czasie zakupiłyśmy dla naszego kościoła albę, komżę i wiele innych rzeczy (...). Od czasu kanonicznego założenia III Zakonu zebrane było zelatorskich i dobrowolnych składek około tysiąc złotych". Kronika Trzeciego Zakonu. reguła Trzeciego Zakonu ${ }^{33}$. Członkowie kongregacji stale zajmowali się także praniem bielizny kościelnej i przyozdabianiem ołtarzy.

Szczególnym darem dla parafii był zakup w roku 1937 ornatu z wizerunkiem św. Franciszka w cenie $230 \mathrm{zt}^{34}$. Wielu tercjarzy od razu zadeklarowało złożenie pewnych sum pieniężnych, dzięki czemu sprawa mogła rychło dojść do szczęśliwego finału. Początkowo planowano prosić o zakup ornatu o. Wiktora Biegusa. Później jednak, za rada ks. Ludwika Bukały, skontaktowano się z siostrami Felicjankami w Przemyślu, które już wcześniej wykonały ornat dla parafii sokołowskiej $^{35}$. Tercjarze zamierzali prosić wizytatora o przybycie na wizytację kongregacji i poświęcenie ornatu w dzień odpustu parafialnego 24 czerwca. Planom tym sprzeciwił sie jednak ks. Ludwik Bukała i przypomniał, że natłok różnych zajęć w dzień odpustu nie sprzyja spokojnemu przeprowadzeniu wizytacji. Ostatecznie ornat poświęcił 11 lipca 1937 r. wizytator o. Cyryl Mameła z zakonu oo. Bernardynów w Rzeszowie.

Po dwóch latach Świecka Rodzina Franciszkańska w Sokołowie kupiła sztandar tercjarski za $580 \mathrm{z}^{36}$. Sztandar ów również zamówiono u sióstr zakonnych w Przemyślu ${ }^{37}$. Sztandar zdobiły dwa wyobrażenia: $z$ jednej strony Matki Boskiej, a z drugiej - św. Franciszka. Było to wotum dziękczynne dla uczczenia siedemsetnej rocznicy przybycia Trzeciego Zakonu do Polski ${ }^{38}$ ${ }^{33}$ Ustawy i zwyczaje, s. 122 .
${ }^{34}$ „S. Sekr. stawia wniosek, aby zakupić nowy biały ornat i to z wizerunkiem św. Franciszka-
a gdy to uchwalono postawiła drugi wniosek, aby tę uchwałę ogłosić wszystkim Siostrom i zachęcić do ofiar na ten cel; nadto aby z miesięcznych składek na początek przeznaczyć 20 zł, które to pien ga protokołów z posiedzeń Dyskretorium III Zakonu w Sokołowie, s. 8

${ }_{35}$ „Przy tej sposobności zwrócono uwagę, że figura św. Franciszka na ornacie nie powinna być zbyt wysoko umieszczona tak aby nad górą św. Franciszka była jeszcze pewna przestrzeń wolna, lub ozdobiona jakimś ornamentem. Nadto ponieważ są w kościele już 2 podobne ornaty z wyhaftowanymi kwiatami maku - należy prosić, aby inne kwiaty np. róże były na ornacie. Ks. Dyrektor oświadczył, że sprawą się zajmie". Tamże, s. 14-15.

36 Osoby, które dały wiekksza kwote na sztandar oraz na ornat: s. Rzeszutek Agnieszka, s. Piękoś Katarzyna, s. Koziarz Katarzyna, s. Aniela Woś, s. Tekla Łuszczka, s. Franciszka Piękoś, s. Eleonora Piękoś, s. Bigos Marya, s. Rzeszutek Agnieszka z Wólki, s. Małgorzata Maksym, s. Cisek Magdalena. Wszystkie inne siostry podały dobrowolnych ofiar w mniejszej kwocie". Kronika Trzeciego Zakonu.

${ }^{37}$ Księga protokołów, s. 46

${ }^{38} \mathrm{O}$ sztandarze tym wspomina dekret wizytacyjny: ,Pięknym czynem tutejszych tercjarzy jest również nowo ufundowany sztandar tercjarski, który odtąd będzie pięknym symbolem, zespalającym wszystkie serca w zbożnej pracy dla dobra Kościoła i dusz własnych". AAW, Kronika Trzeciego Zakonu, C. Mameła, Dekret Wizytacyjny z 6 sierpnia 1939 r. 
Tercjarze sokołowscy założyli własną bibliotekę ${ }^{39}$. Gromadzono w niej głównie książki o tematyce religijnej ${ }^{40}$. W ciagu trzech lat zbiory biblioteczne osiągnęły 114 pozycji wydawniczych ${ }^{41}$. Książki były „przeważnie dobrowolnie ofiarowane od osób rozumiejących cel III Zakonu"42. Oprócz tego prenumerowano różne czasopisma, zwłaszcza „Dzwonek Trzeciego Zakonu”, „Posłańca Serca Jezusowego" i „Rycerza Niepokalanej” ${ }^{43}$. Czytelnictwo tych periodyków było wśród członków kongregacji bardzo rozpowszechnione.

Wszelka działalność sokołowskich tercjarzy opierała się przede wszystkim na własnej formacji duchowej prowadzonej we wspólnocie zakonnej. Co miesiąc cała kongregacja gromadziła się na wspólnym zebraniu. Te publiczne zgromadzenia miały miejsce w kościele farnym. O tym, co się działo na nich, pisał kronikarz tercjarski: „ks. Dziekan Bukała wygłasza lub czyta coś budującego o III Zakonie".

Oprócz tych oficjalnych zebrań odbywały się także zgromadzenia prywatne, najczęściej w Sokołowie, w domu s. Eleonory Piękoś, która piastowała funkcję mistrzyni nowicjatu. Na spotkania te w głównej mierze składały się modlitwy i czytania duchowne; nie uczestniczył w nich kapłan. Trudno rzec czy spotkania te gromadziły wszystkich tercjarzy, czy były to tylko spotkania nowicjuszy i postulantów. Bardziej przemawiająca wydaje sie druga z tych możliwości, gdyż mistrzyni nowicjatu już ze swej funkcji miała obowiązek zaznajamiać postulantów $\mathrm{z}$ istotą tercjarstwa, a nowicjuszy przysposobić do pełnego i aktywnego uczestnictwa w życiu Trzeciego Zakonu.

W ciagu pierwszych trzech lat istnienia kongregacji odbyło się też 19 posiedzeń dyskretorium. Były to tzw. „narady starszych”. Na zebranie przybywali wszyscy tercjarze zajmujący stanowiska w sokołowskiej kongregacji. Uczestniczył w nich także dyrektor, spotkania prowadziła jednak siostra przełożona. Obrady poświęcone były sprawom związanym z miejscowym Trzecim Zakonem. Rozpatrywano zatem m.in. przyjmowanie lub odrzucanie kandydatów do tercjarstwa,

${ }^{39}$ Reguła tercjarzy nie nakazywała ani nawet nie zachęcała do zakładania własnych bibliotek zakonnych. Mimo to wielu jej komentatorów polecało to czynić. Por. Cz. Bogdalski, Organizacja i działalność III Zakonu, s. 102. Wypożyczanie ksiażek z takiej biblioteki było bezpłatne, lecz korzystać z niej mogli jedynie członkowie kongregacji, gdyż ksiażki były przeznaczone tylko do ich wyłącznego użytku.

${ }^{40}$ Początkowo kilka książek wypożyczała mistrzyni. Później korzystano także z książek z biblioteki parafialnej. „S. Mistrzyni ma kilkanaście książek treści religijnej bądź własne, bądź darowane od innych osób. Zebrane uchwalaja wypożyczyć kilkanaście ksiażek treści religijnej z parafialnej wypożyczalni książek". Księga protokołów, s. 28

${ }^{41}$ Już 28 listopada 1937 r. kongregacja posiadała 45 książek o tematyce religijnej. Liczba pozycji szybko wzrastała, przykładowo p. Sywulakowa ofiarowała 29 książek, po dwie Aniela Piękosiowa i p. Ukowska z Wólki Sokołowskiej, zaś jedną - Eleonora Piękoś. W późniejszym czasie bibliotekę wzbogaciło 26 książek pochodzących z daru od p. Dańczakowej, p. Czerkawskiej i p. Sywulakowej. Tamże, s. 29, 35, 41, 49.

${ }^{42}$ Kronika Trzeciego Zakonu.

${ }^{43}$ „Uchwalono z Kasy prenumerować 1 «Dzwonek» (...)”. Księga protokołów, s. 32. dopuszczano do profesji, łagodzono zaistniałe konflikty, omawiano prowadzoną działalnośćc ${ }^{4}$

Każde posiedzenie zaczynało się modlitwą, później odczytywano protokół z poprzedniego spotkania. Siostra przełożona przedstawiała sprawozdanie z wykorzystywania zebranych ofiar i z wszelkich podejmowanych działań. Podejmowano także decyzje, dotyczace zamawiania stypendiów mszalnych i innych wydatków. Nastepnie członkowie dyskretorium zgłaszali wolne wnioski, które poddawano pod dyskusje i zatwierdzano lub odrzucano. Spotkanie podsumowywał ksiądz dyrektor, wyznaczając także czasem tercjarzom zadanie do spełnienia. Zebranie kończono zawsze modlitwami. Tematykę obrad sokołowskiego dyskretorium w latach $1936-1939$ i

\begin{tabular}{|c|c|c|}
\hline Data & Tematyka obrad & Wnioski \\
\hline 1 & 2 & 3 \\
\hline 1.8 .1936 & $\begin{array}{l}\text { Podsumowanie działalności III Zakonu } \\
\text { w Sokołowie do czasu kanonicznej erek- } \\
\text { cji. }\end{array}$ & $\begin{array}{l}\text { Umieścić wzmiankę o zmarłych człon- } \\
\text { kach III Zakonu w Kronice. Wpisać } \\
\text { siostry przyjęte przez ks. Leona Szado } \\
\text { do Księgi czlonków. }\end{array}$ \\
\hline 13.9 .1936 & $\begin{array}{l}\text { Sprawozdanie z pomocy } \\
\text { w prymicjach ks. Łucjana Łuszczkiego. } \\
\text { Zawiadomienie o zamówieniu pieczatki } \\
\text { III Zakonu w Sokołowie. }\end{array}$ & $\begin{array}{l}\text { Zachęcać członków Stowarzyszenia Pań } \\
\text { Miłosierdzia i KSM do wstępowania do } \\
\text { III Zakonu. Odwiedzać chore osoby. } \\
\text { Apelować do matek, by zakazywały } \\
\text { dziewczętom uczęszczać na zabawy } \\
\text { taneczne. Zakupić nowy ornat ze św. } \\
\text { Franciszkiem. }\end{array}$ \\
\hline 8.10 .1936 & $\begin{array}{l}\text { Omówienie sprawy składek miesięcz- } \\
\text { nych. }\end{array}$ & $\begin{array}{l}\text { Zwolnić dwie członkinie z obowiązku } \\
\text { spłacenia zaległych składek. }\end{array}$ \\
\hline 24.1.1937 & $\begin{array}{l}\text { Sprawozdanie z opłatka. Sprawa zakupu } \\
\text { ornatu. Sprawa przyjęcia kilku nowych } \\
\text { członkiń. }\end{array}$ & $\begin{array}{l}\text { Zorganizować przez trzy dni wspólną } \\
\text { adorację godzinną podczas nabożeństwa } \\
40 \text {-godzinnego o } 13^{00} \text {. }\end{array}$ \\
\hline 28.2 .1937 & $\begin{array}{l}\text { Sprawa zakupu ornatu. Kwestia zapisów } \\
\text { w Księdze kasowej. }\end{array}$ & $\begin{array}{l}\text { Prosić organistę, by przy przyjęciu no- } \\
\text { wych sióstr śpiewał i grał Veni Creator. } \\
\text { Odprawić adorację przy Bożym Grobie. }\end{array}$ \\
\hline 25.4 .1937 & $\begin{array}{l}\text { Sprawa zakupu ornatu i zgłaszania się } \\
\text { kandydatów. }\end{array}$ & $\begin{array}{l}\text { Wstępować w szeregi Akcji Katolickiej, } \\
\text { zwł. Katolickiego Stowarzyszenia Ko- } \\
\text { biet. Apelować, by organista uczył śpie- } \\
\text { wu. }\end{array}$ \\
\hline 6.6 .1937 & $\begin{array}{l}\text { Sprawa zakupienia świec. Sprawa wizy- } \\
\text { tacji. Sprawa egzaminu nowicjuszek. }\end{array}$ & $\begin{array}{l}\text { Porozumieć się z O. Wizytatorem z } \\
\text { Rzeszowa w sprawie przeprowadzenia } \\
\text { wizytacji miejscowej Kongregacji III } \\
\text { Zakonu. }\end{array}$ \\
\hline 17.10.1937 & Sprawy finansowe. Sprawa kandydatek. & $\begin{array}{l}\text { Zapalać świece w kościele w czasie } \\
\text { zebrania miesięcznego. }\end{array}$ \\
\hline
\end{tabular}

${ }^{44}$ Bogdalski, Organizacja i dzialalność III Zakonu, s. 69-72.

${ }^{45}$ Ksiegga protokołów, s. 1-51. 


\begin{tabular}{|c|c|c|}
\hline 1 & 2 & 3 \\
\hline 28.11.1937 & $\begin{array}{l}\text { Sprawozdanie z działalności biblioteki. } \\
\text { Kandydatki do obłóczyn i do profesji. }\end{array}$ & $\begin{array}{l}\text { Zakupić ławki potrzebne na zebrania } \\
\text { u siostry mistrzyni nowicjatu. Urządzić } \\
\text { wspólny opłatek } 6 \text { stycznia przyszłego } \\
\text { roku. }\end{array}$ \\
\hline 30.1 .1938 & $\begin{array}{l}\text { Sprawa zakupienia sztandaru. Sprawa } \\
\text { zaniedbywania przez część sióstr udziału } \\
\text { w nabożeństwach. }\end{array}$ & $\begin{array}{l}\text { Prenumerować „Dzwonek III Zakonu”. } \\
\text { Zorganizować przez trzy dni o } 13^{\circ 0} \\
\text { wspólną adorację godzinną podczas } \\
\text { nabożeństwa } 40 \text {-godzinnego. Odmawiać } \\
\text { różaniec przy zmarłych. }\end{array}$ \\
\hline 21.3.1938 & $\begin{array}{l}\text { Sprawa wyjazdu do Wilna. Zgłoszenie } \\
\text { osób do profesji. Sprawozdanie z dzia- } \\
\text { łalności biblioteki. Sprawa książki pa- } \\
\text { miątkowej Zjazdu Tercjarskiego. }\end{array}$ & $\begin{array}{l}\text { Składać dobrowolne składki na budowę } \\
\text { domu rekolekcyjnego w Leżajsku. Zło- } \\
\text { żyć } 10 \text { zł na wykupienie klasztoru SS. } \\
\text { Ubogich z rąk żydowskich. Zorganizo- } \\
\text { wanie wspólnej adoracji godzinnej o } 13^{00} \\
\text { w Wielki Piątek. }\end{array}$ \\
\hline 25.5 .1938 & $\begin{array}{l}\text { Sprawa zaproszenia o. wizytatora. Spra- } \\
\text { wa bielizny mszalnej. }\end{array}$ & $\begin{array}{l}\text { Kupić } 1 \text { egz. Katalogu tercyarskiego. } \\
\text { Zwołać ogólne zebranie w drugą nie- } \\
\text { dzielę czerwca u siostry Mistrzyni. }\end{array}$ \\
\hline 25.9.1938 & $\begin{array}{l}\text { Sprawa odnowienia procesyjnego krzyża } \\
\text { i berła }\end{array}$ & $\begin{array}{l}\text { Wpisać do Kroniki poprawioną historię } \\
\text { powstania Kongregacji III Zakonu }\end{array}$ \\
\hline 20.11.1938 & $\begin{array}{l}\text { Sprawa czyszczenia bielizny kościelnej. } \\
\text { Sprawa Papieskich Dzieł Misyjnych. } \\
\text { Zgłoszenie } 5 \text { osób do profesji. }\end{array}$ & $\begin{array}{l}\text { Zwołać walne zebranie } 8 \text { grudnia } \\
\text { w sprawie zorganizowania opłatka. Za- } \\
\text { pisać się do Papieskiego Dzieła św. } \\
\text { Piotra i Rozkrzewiania Wiary. Zaopieko- } \\
\text { wać się p. Węglowską z ul. Rzeszow- } \\
\text { skiej i innymi po wsiach. }\end{array}$ \\
\hline 2.2 .1939 & $\begin{array}{l}\text { Sprawa opłatka. Sprawa dyskrecji i } \\
\text { tajemnicy tematyki obrad. }\end{array}$ & $\begin{array}{l}\text { Wzięcie udziału w nabożeństwie 40- } \\
\text { godzinnym jak co roku. Usunąc z kon- } \\
\text { gregacji M. Piękosiównę. }\end{array}$ \\
\hline 19.3.1939 & $\begin{array}{l}\text { Sprawa sztandaru. Zgłoszenie się trzech } \\
\text { kandydatek do } \\
\text { III Zakonu. }\end{array}$ & $\begin{array}{l}\text { Zwołać walne zebranie w sprawie świę- } \\
\text { conego. Przygotować adorację w Wiel- } \\
\text { kim Tygodniu. }\end{array}$ \\
\hline 21.5.1939 & Sprawa pielgrzymki do Częstochowy. & $\begin{array}{l}\text { Prosić wizytatora o poświęcenie sztan- } \\
\text { daru, gdy ten będzie gotowy. }\end{array}$ \\
\hline 28.6.1939 & $\begin{array}{l}\text { Sprawa pielgrzymki } \\
\text { do Częstochowy. }\end{array}$ & Zaprosić wizytatora na dzien 30 lipca. \\
\hline
\end{tabular}

Do roku 1939 tercjarze byli fundatorami 22 stypendiów mszalnych; sześć z tych Mszy św. ofiarowanych zostało za zmarłe siostry. Członkowie Zakonu dwa razy w roku prowadzili publiczną adorację Najświętszego Sakramentu - na początku Wielkiego Postu (podczas Nabożeństwa Czterdziestogodzinnego) i w Wielki Piątek. Organizowali także różne spotkania z okazji świąt kościelnych - przykładowo raz święcone, a dwa razy opłatek.

Wiele zawdzięczał Trzeci Zakon osobie dyrektora ks. Ludwika Bukały. Nie tylko założył on kongregację i jej przewodniczył, ale także miał o nią troskliwe staranie. Stwierdzali to wizytatorzy, wspominał o tym też w wielu miejscach kro- nikarz tercjarski. Przekazał on m.in.: „Wszystko cokolwiek III Zakon uczynił dla dobra kościoła możemy jednie zawdzięczać Ks. Dyrektorowi, bo naprawdę jako Ojciec najlepszy rozumie nasze potrzeby i badź to dobrą radą i pouczeniem działał zawsze na korzyść III Zakonu, dla którego nie żałował trudu ni pracy” i „Gdy Tercyarstwo ma tak dzielnego i rozumnego Dyrektora to mamy w Bogu nadzieję, że odtąd pomyślniej rozwijać się będzie"46

Od kanonicznego zaprowadzenia Trzeciego Zakonu w Sokołowie do sierpnia 1939 roku miejsce miały dwie wizytacje tejże kongregacji. Obu dokonał o. Cyryl Mameła z Rzeszowa. Pierwsza kontrola odbyła się 11 lipca 1937 r., druga zaś dwa lata później - 6 sierpnia 1939 r. O pierwszej wizytacji nie wiadomo wiele ${ }^{47}$. Miała ona zapewne na celu sprawdzenie, jak potoczyły się losy erygowanego przed rokiem Zakonu. Wizytator badał bowiem, czy prowadzony jest on poprawnie i czy nie wymagana jest interwencja ze strony wyższych władz Zakonu. Ze szczególną uwagą wizytator przyglądał się obranemu zarządowi. Osądzał też, czy staje on na wysokości zadania.

Jak wynika $\mathrm{z}$ dekretu wizytacyjnego wydanego podczas następnej wizytacji przez o Cyryla Mameła, stan sokołowskiego tercjarstwa był bardzo dobry, a ono samo rozwijało się pomyślnie. Wizytator docenił zwłaszcza solidną i spełnianą z pełnym oddaniem i zaangażowaniem pracę zarządu oraz przychylność i troskę proboszcza ${ }^{48}$. Wizytacja przebiegała zapewne według czterech punktów. Po modlitwach albo uroczystym nabożeństwie odbyła się konferencja wizytatora z dyrektorem ks. Ludwikiem Bukała. Później nastapiło zbadanie ksiag tercjarskich, a następnie konferencja wizytatora z siostrą przełożoną i dyskretorium. Ostatnim elementem wizytacji było spotkanie o. Cyryla Mameły z wszystkimi tercjarzami sokołowskimi ${ }^{49}$.

Drugą wizytację przeprowadził ten sam zakonnik. Oprócz konferencji z dyrektorem, siostra przełożona i dyskretorium oraz wszystkimi tercjarzami, miejsce miały dwa ważne dla tutejszej wspólnoty wydarzenia. Pierwszym było poświęcenie nowego sztandaru tercjarskiego, którego o godz. $10^{00}$ dokonał o. Cyryl Mamała. Było to o tyle ważne, że sztandar stanowił widomy znak istnienia i działalności tercjarzy. Odtąd występowali pod nim podczas wszystkich większych uroczystości religijnych.

O wydarzeniu tym kronikarz tercjarski pisał następującymi słowami: „Po uroczystym poświęceniu odbyła sie ceremonia wbijania gwoździ. Poczym wygłosił Przewielebny O Wizytator podniosłą mowę, w której zachęcał Tercjarzy do wspól-

\section{${ }^{46}$ Kronika Trzeciego Zakonu.}

${ }^{47}$ Kronika tercjarska podaje sucho: „W dniu 11 lipca 1937 r. przybył do naszej [Kongregacji] O. Wizytator Cyryl Mameła [z klasztoru] OO. Bernardynów z Rzeszowa celem zaznajomienia się ze sprawami III Zakonu oraz odbycia wizytacji". Tamże.

${ }^{48}$ C. Mameła op cit. Dnia 6 sierpnia 1939 odbyłem już po raz wtóry kanoniczną wizytację III Zakonu św. Franciszka w Sokołowie. Stwierdziłem i tym razem wielką gorliwość tercjarzy w pracy na niwie franciszkańskiej. Na specjalną pochwalę i uznanie zasługuje zwłaszcza Zarząd (...). Wyrażam uznanie i gorące dzięki Przewielebnemu ks. Dyrektorowi Ludwikowi Bukale, który cała duszą przyczynił się do rozwoju tutejszej Kongregacji tercjarskiej".

${ }^{49}$ Por. Bogdalski, Organizacja i dzialalność III Zakonu, s. 116-118. 
nych wysiłków obronie wiary św. i Kościoła Katolickiego. (...) Potym odbyła się uroczysta suma, którą odprawił Przewielebny nasz Ks. Dyrektor, a w czasie której miał znów kazanie Przewielebny O. Wizytator, a całe osnute na tle życia św. Franciszka. (...) Kazanie kończyło się wreszcie zachętą, aby w poczet tercjarzy wpisywali się nie tylko starzy, ale i młodzieńcy i panienki (...)"s50.

Kolejnym wydarzeniem, jakie miało miejsce podczas wizytacji 6 sierpnia 1939 r., był wybór nowego zarządu kongregacji. Przygotowaniem do niego było odśpiewanie przez całą wspólnotę tercjarską pieśni do Ducha Świętego. Miejscem dokonania wyboru była plebania, w której wszyscy członkowie Trzeciego Zakonu dokonali elekcji nowego dyskretorium.

W wybranym wówczas zarządzie osoby na kluczowych stanowiskach pozostały niezmienione. Dokładniejsze informacje o tym zapisano w kronice tercjarskiej: „I tak przełożoną została nadal Katarzyna Koziarz i tak w ogóle nic się w Zarządzie nie zmieniło z tym małym wyjątkiem, że Skarbniczka podała się do dymisji, a to z powodu choroby, a Sekretarce i Zakrystjance ${ }^{51}$ przydano pomoc"s2. Innymi posunięciami było utworzenie osobnych funkcji infirmerek dla wsi wchodzących w skład parafii i zmiana zelatorki dla Trzebuski - stanowisko to objęła Maria Motyl. Wybór zaakceptowano niemal jednogłośnie. Zakończeniem wizytacji było odmówienie modlitw w kościele parafialnym. Skład zarządu kongregacji sokołowskiej II kadencji przedstawia zamieszczona niżej tabela.

\begin{tabular}{|c|c|c|c|}
\hline \multirow{2}{*}{\multicolumn{3}{|c|}{$\begin{array}{l}\text { Funkcja w zarzadzie } \\
\text { Dyrektor }\end{array}$}} & \multirow{3}{*}{\begin{tabular}{|l|}
\multicolumn{1}{|c|}{ Imię i nazwisko } \\
Ks. Ludwik Bukała \\
Katarzyna Koziarz
\end{tabular}} \\
\hline & & & \\
\hline \multirow{19}{*}{ 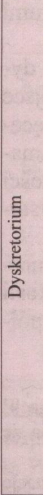 } & \multicolumn{2}{|c|}{$\begin{array}{l}\text { Dyrektor } \\
\text { Siostra przełożona }\end{array}$} & \\
\hline & \multicolumn{2}{|c|}{ Siostra asystentka I } & Franciszka Krauz z Trzebuski \\
\hline & \multicolumn{2}{|c|}{ Siostra asystentka II } & Małgorzata Maksym z Wólki Sokołowskiej \\
\hline & \multicolumn{2}{|c|}{ Siostra mistrzyni nowicjatu } & Eleonora Piękoś z Sokołowa \\
\hline & \multicolumn{2}{|c|}{ Siostra sekretarka } & Aniela Piękoś z Sokołowa \\
\hline & \multicolumn{2}{|c|}{ Siostra zastępezyni sekretarki } & Zofia Ożóg \\
\hline & \multicolumn{2}{|c|}{ Siostra skarbniczka } & Agnieszka Rzeszutek \\
\hline & \multicolumn{2}{|c|}{ Siostra zakrystianka I } & Julia Sączawa \\
\hline & \multicolumn{2}{|c|}{ Siostra zakrystianka II } & Franciszka Krauz \\
\hline & \multirow{5}{*}{ 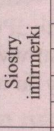 } & dla Sokołowa & Franciszka Węglowska \\
\hline & & dla Wólki Sokołowskiej & Franciszka Kuc \\
\hline & & dla Turzy & Anna Surowiec \\
\hline & & dla Trzebuski & Franciszka Krauz \\
\hline & & dla Rękawa & Katarzyna Dudek \\
\hline & \multirow{5}{*}{ 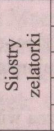 } & dla Rękawa & Aniela Bąk \\
\hline & & dla Sokołowa & Maria Koziarz \\
\hline & & dla Trzebuski & Maria Motyl \\
\hline & & dla Turzy & Zofia Sikora \\
\hline & & dla Wólki Sokołowskiej & Julia Maksym, Agnieszka Szób, Katarzyna Rychel \\
\hline
\end{tabular}

${ }^{50}$ Kronika Trzeciego Zakonu.

${ }^{51}$ Wynika z tego, że do roku 1939 dokonano wyboru lub nominacji na urzędy skarbniczki i zakrystianki. Trudno stwierdzić, kiedy to nastapiło, gdyż milczą o tym źródła.

${ }^{52}$ Kronika Trzeciego Zakonu.
Trudno określić, ilu członków liczyła sokołowska wspólnota Swieckiej Rodziny Franciszkańskiej. Kronika tercjarska wspomina, że w latach 1921-1935 przyjęto do niej 62 osoby $^{53}$. Jeśli dodać do tego pewną liczbę osób, które wcześniej złożyły profesje, wydaje sie że była to dosyć duża grupa parafian. Pamiętać też trzeba, iż od roku 1890 do roku 1935 wielu członków Trzeciego Zakonu zmar$\mathfrak{ł o}^{54}$. W dniu założenia kongregacja liczyła około stu osób.

Liczba ta zwiekszyła sie znacznie do wybuchu II wojny światowej. Przez trzy lata kanonicznego istnienia Trzeciego Zakonu w Sokołowie zmarły trzy należące do niego siostry ${ }^{55}$. W tym samym czasie miejsce miało 30 obłóczyn i 30 osób przebywało w nowicjacie, profesję zakonną złożyło natomiast 28 osób. Do grona tercjarzy przyjęto również Katarzynę Krawczyk, która już wcześniej była tercjar$\mathrm{ka}^{56}$. Ze kongregacji wyłoniło się także wiele powołań zakonnych do różnych żeńskich zakonów regularnych ${ }^{57}$.

Warte zauważenia jest, że członkowie sokołowskiej kongregacji nie tworzyli zamkniętej grupy, nie angażującej się nigdzie poza własną wspólnotą. Uwidaczniała sie zwłaszcza współpraca z bractwami, organizacjami i stowarzyszeniami kościelnymi. Kronikarz tercjarski pisał o tym: „Wszyscy bez wyjątku Tercyarze należą do różnych bractw kościelnych, jako to do Apostolstwa Serca Jezusowego, Bractwa Różańca św., Bractwa Szkaplerza, Bractwa Straży Honorowej, Bractwa Adoracji Najświętszego Sakramentu"58. Dwie tercjarki - Maria Koziarz i Zofia Sikora - były nawet prezeskami w tych zrzeszeniach. Osiem sióstr wstapiło również do Papieskiego Dzieła św. Piotra Apostoła w Sokołowie. Ich imiona i nazwiska zostały wymienione w księgach zakonnych ${ }^{59}$.

Zastanawiać może, że Franciszkański Zakon Świeckich w Sokołowie był w praktyce zdominowany przez kobiety ${ }^{60}$. To siostry stanowiły zarząd, prowadziły działalność zakonną, były fundatorkami sprzętów liturgicznych i kościelnych

${ }^{53}$ Liczbe te potwierdza Ksiega protokołów z posiedzeń Dyskretorium. Mówi ona także, że dokładną imienną listę osób zawierała zaginiona Księga Stowarzyszenia Różańca Żywego. Por. Księga protokołów, s. 2.

${ }^{54}$ Por. Kronika Trzeciego Zakonu. Dokument ten podaje dokładniejsze dane na ten tema Wśród zmarłych było troje sokołowian: Andrzej Hodała, Andrzej Sidor i Maria Sidor oraz jedenaście mie Kania, Wiktoria Matuła, Zofia Matuła, Marianna Nizioł, Maria Ożóg, Agnieszka Rzeszutek, Zofia Kania, Wiktoria Mát

${ }^{55}$ Nekrologi zmarłych sióstr zamieszczono w „Dzwonku Trzeciego Zakonu”.

${ }^{56}$ Siostra ta, mieszkająa poza obszarem parafii, należała jako panna do Trzeciego Zakonu. Po wyjściu za maż za tutejszego parafianina zamieszkała na stałe w Sokołowie.

${ }^{57}$,Z Wólki Sokołowskiej wstapiły do Zakonu następujące osoby: Marja Nizioł do sióstr Maryanek, Katarzyna Falandys wstapiła do Zakonu Franciszkańskiego w Ameryce, Magdalena Bigos do sióstr Maryanek. Z Rękawa - Agnieszka Kołodziej do Zgromadzenia Sióstr Rodziny Maryi. Do tegoż Zgromadzenia wstapiła także Katarzyna Rakuś i Agnieszka Nowak. I wreszcie z Turzy - Wiktorya Smolak i Matuła Ewa do Sióstr Felicyanek". Kronika Trzeciego Zakonu.

${ }^{58}$ Tamże.

${ }^{59}$ Księga protokołów, s. 44

${ }^{60}$ Podobny fakt zanotowano i w innych zgromadzeniach Trzeciego Zakonu, przykładowo w Górnie i w Rzeszowie. Por. Ożóg, Dzieje parafii Górno, s. 139; Motyka, Życie religijne, s. 182. 
Jednocześnie kongregacja nie była wspólnotą typowo żeńską. Kronika tercjarska na wielu miejscach mówi co prawda o członkach Zakonu: „siostry”, ,nowicjuszki”, , uchwaliły”, ,zakupiłyśmy”, ale nie wydaje się prawdopodobne, by miały go tworzyć wyłącznie kobiety. Zresztą ta sama kronika podaje zarazem nazwiska i imiona mężczyzn-tercjarzy z Sokołowa.

Prawdopodobnie sokołowska gmina tercjarska była ze swej natury kobieca ale w swoich szeregach skupiała także mężczyzn. Stan taki traktowano jako tymczasowy, licząc na zaprowadzenie w najbliższym czasie odrębnej części gminy, do której należeć mieli tylko mężczyźni. Osobnego oddziału męskiego jednak nie utworzono, a przynajmniej nie ma o tym mowy w żadnych znanych dokumentach archiwalnych. Nie wydaje się wszakże, by przyczyną niezaistnienia meskiej części gminy była mała ilość mężczyzn w Trzecim Zakonie. Do założenia nowej kongregacji wystarczało bowiem na początku nawet niewielka liczba osób. Bardziej prawdopodobne jest to, że tercjarze próbowali utworzyć taką „,męską" część gminy, lecz wybuch II wojny światowej, jaki miał miejsce już w trzy lata po erekcji kongregacji, uniemożliwił realizację tych planów ${ }^{61}$.

${ }^{61}$ Por. Bogdalski, Organizacja i dzialalność III Zakonu, s. 28.

\section{THE FOUNDATION AND ACTIVITY OF THE THIRD ORDER}

OF ST FRANCIS IN SOKOLOW MALOPOLSKI TO 1939

\section{Summary}

At the turn of the $19^{\text {th }}$ and $20^{\text {th }}$ centuries lots of religious communities were founded in the $\mathrm{St}$ John Baptist parish in Sokołów Małopolski. One of the most important was the Third Order of St Francis. Its foundation was preceded by many years of endeavours. The very idea was propagated by the inhabitant of Sokołów, Katarzyna Koziarz, who became the member of the secular family of Franciscan family in Rzeszów in 1890. Since then more and more people from Sokołów had joined the Tertiary.

At the beginning of the $20^{\text {th }}$ century those who took steps to popularize the Third Order were Katarzyna Koziarz in Sokołów, Maria Ożóg and Małgorzata Maksym in Wólka Sokołowska and Katarzyna Bak in Trzebuska while the parish priests, Franciszek Stankiewicz and Leon Szado did little for this matter. The members of the Third Order got involved in lots of activities such as supporting the building of the church, providing necessary things for the church and making mass offerings.

Serious steps to found the Third Order in Sokołów were taken by the parish priest Ludwik Bukała. He organized monthly meetings for the Third Order members. He also established contact with the Bernardine Father, Wiktor Biegus, who 27 April 1936 came to Sokołów and became acwith the Bernardine Father, Wiktor Biegus, who 27 April 1936 came to Sokolow and became accongregation was granted 4 May 1936 by the ordinary of Przemyśl, Bishop Franciszek Bard.

The official foundation of the congregation in Sokołów took place 24 May 1936. The local tertiaries chose St Ludwik as their patron. The congregation government was constituted at the first meeting. The parish priest became the director of the community and Katarzyna Koziarz was appointed the superior. On the day of the foundation there were about 100 members. In the first three pointed the superior. On the day of the foundation there were about 100 members. In the first three
years of the existence of the Third Order there were 30 people who received the habits and 28 who years of the existence of the Third
were admitted to the profession.

After the canonical establishment of the congregation, the tertiaries became more active. They provided the church with sacred appurtenances and furnishings, as well as organising public adoration of the Holy Sacrament. They would also wash liturgical linens and adorn altars. In 1937 they tion of the Holy Sacrament. They would also wash liturgical linens and adorn altars. In of Mother of God and St Francis. In addition, the tertiaries founded their own library with religious books and magazines.

The congregation gathered for meetings in the parish church every month. Besides, they had occasional private gatherings. In the first years of the existence of the congregation there were 19 meetings of the Counsel. There were also two visitations of the Sokolów congregation held by Father Cyryl from Rzeszów 11 July 1937 and 6 August 1939. The activities of the tertiaries were hindered by the outbreak of the Second World War. 